\title{
Arbitrability and Public Interest in International Commercial Arbitration ${ }^{1}$
}

\author{
Klára Drličková \\ Department of International and European Law, \\ Faculty of Law, Masaryk University \\ klara.drlickova@law.muni.cz
}

DRLIČKOVÁ, Klára. Arbitrability and Public Interest in International Commercial Arbitration. International and Comparative Law Review, 2017, vol. 17, no. 2, pp. 55-71. DOI 10.2478/iclr-2018-0015.

\begin{abstract}
Summary: The aim of this article is to analyse the mutual relationship between arbitrability and public interest. The definition of arbitrability has remained in the domain of national law; there is no internationally unified definition, although a common trend towards the extension of its scope may be observed. There is no doubt about arbitrability in disputes concerning only the individual interests of the parties. However, if the dispute shows elements of public interest, it does not automatically imply that it is not arbitrable. A sign of equation thus cannot be put between public interest and inarbitrability. Disputes arising from economic activities involving public interest can be resolved before the arbitral tribunals. This for instance includes private-law enforcement of competition rules (including EU ones), disputes affected by illegal (criminal) actions, disputes concerning intellectual property rights (in certain countries also with erga omnes effects) or disputes related to insolvency proceedings.
\end{abstract}

Keywords: international commercial arbitration, public interest, arbitrability, competition law, criminal law, intellectual property rights, insolvency

\section{Introduction}

International commercial arbitration is currently the preferred method of resolution of disputes originating from international business transactions, and it represents a full-fledged alternative to dispute resolution before national courts. With the growing volume of international trade, the international commercial arbitration has become an increasingly utilized instrument. It is not only the number, but also the diversity and complexity of disputes that have been growing. Arbitrators often face disputes going beyond the individual interests of the parties to arbitration. They also deal with disputes related to public interests. In this context, we must inquire into the arbitrability of such disputes. Arbitrability has been traditionally associated with the interest of states to leave certain areas

1 This article is created within the project supported by the Grant Agency of the Czech Republic GA15-08182S The Role of Public Interest in International Commercial and Investment Arbitration. 
of disputes exclusively in the hands of national courts; this in particular includes disputes concerning public interests. However, we have recently witnessed the tendency to expand the scope of arbitrability.

The aim of this article is to analyse the mutual relationship between arbitrability and public interest. The text also provides evaluation of the existing situation in arbitrability of disputes associated with public interests. The current topic of the international commercial arbitration is disputes requiring the application of competition rules including the EU ones, and disputes affected by illegal (criminal) acts such as corruption. The article will also focus on disputes concerning intellectual property rights and disputes involving insolvency proceedings.

\section{Several Remarks on Arbitrability}

The term arbitrability is used in several meanings. ${ }^{2}$ For the purposes of this text, arbitrability is understood as an admissibility of a dispute to be solved in arbitration proceedings. In other words, determination of the group of disputes which, under a legal order, can be decided in arbitration. Such understanding of arbitrability is sometimes referred to as objective arbitrability (arbitrability rationae materie). ${ }^{3}$ The definition of arbitrability is an issue of national legislations; there is no single international or transnational definition of arbitrability. Although we have witnessed common tendencies in recent decades, differences among individual countries still exist. Thus, it depends on who (arbitrator or court) and in which stage of the process shall assess arbitrability.

The issue of arbitrability may arise before national courts both in the stage of enforceability of an arbitration agreement and in the stage of annulment or recognition and enforcement of an arbitral award. In this context, the regulation provided for by the New York Convention ${ }^{4}$ is particularly relevant. Article II(1) of the New York Convention stipulates that the Contracting States shall recognize an arbitration agreement related to an arbitrable dispute. Article II, however, does not determine the law under which arbitrability should be assessed. Opinions vary. The most convincing opinion says that the courts should use their own law (lex fori), on the basis of analogous application of Article $\mathrm{V}(2)$

2 For example in the United States arbitrability includes all issues of arbitrators' jurisdiction (see e.g. SHORE, Laurence. The United States' Perspective on „Arbitrability“. In: MISTELIS, Loukas A., BREKOULAKIS, Stavros L. (eds). Arbitrability: International \& Comparative Perspective. Alphen aan den Rijn: Kluwer Law International, 2009, p. 70). The notion of arbitrability is also used for the scope of arbitration agreement (see e.g. ROZEHNALOVÁ, Naděžda. Rozhodči řizení v mezinárodním a vnitrostátním obchodním styku. 3rd ed. Praha: Wolters Kluwer ČR, 2013, p. 144).

3 BORN, Gary B. International Commercial Arbitration. 2nd ed. Alphen aan den Rijn: Kluwer Law International, 2014, p. 944; ROZEHNALOVÁ, 2013, op. cit., p. 143.

4 Convention on the Recognition and Enforcement of Foreign Arbitral Awards (New York, 1958). 
(a). ${ }^{5}$ This view is also supported by the case law. ${ }^{6}$ In the stage of recognition and enforcement of the award, Article V(2)(a) of the New York Convention shall apply. According to this provision, the law of the country where recognition and enforcement are sought shall be decisive for the assessment of arbitrability.

In the arbitration proceedings, several ways of determination of the law applicable to arbitrability have arisen. ${ }^{7}$ It seems that the law applicable to arbitration (lex arbitri) is the most favoured one. ${ }^{8}$

Although the New York Convention does not define arbitrability, the Contracting States must not hamper the goals of the Convention by their definitions of arbitrability. There are certain limitations ensuing from the New York Convention. First, a state must not declare all disputes (or broad categories of disputes) inarbitrable. Inarbitrability should be an exception justified by important public interests. Second, Contracting States must not discriminate between national and international disputes. In case a certain dispute is arbitrable in the national context, it must be arbitrable also if it contains an international element. ${ }^{9}$

Arbitrability is usually broadly defined in modern regulations of arbitration. The definition is either contained directly in the legal acts on or is implied by means of case law (this is typical for common law countries ${ }^{10}$ ). Arbitrability definitions are usually based on proprietary (economic) nature of claims ${ }^{11}$ or

5 BORN, 2014, op. cit., p. 599; MISTELIS, Loukas A. Arbitrability - International and Comparative Perspectives. In: MISTELIS, Loukas A., BREKOULAKIS, Stavros L. (eds). Arbitrability: International \& Comparative Perspective. Alphen aan den Rijn: Kluwer Law International, 2009, p. 12; LEW, Julian D. M., MISTELIS, Loukas A., KRÖLL, Stefan M. Comparative International Commercial Arbitration. The Hague: Kluwer Law International, 2003, p. 191; VAN DEN BERG, Albert J. The New York Arbitration Convention of 1958. The Hague: T. M. C. Asser Institute, 1981, pp. 152-153.

6 BORN, 2014, op. cit., s. 602; see Report on the Concept of Arbitrability under the New York Convention [online]. IBA Subcommittee on Recognition and Enforcement of Arbitral Awards, 2016, point 39. Available at: http://www.ibanet.org/ Accessed: 30.11.2017.

7 LEW, MISTELIS, KRÖLL, 2003, op. cit., p. 196.

8 MISTELIS, 2009, op. cit., p. 13.

9 BORN, 2014, op. cit., pp. 611-615; QUINKE, David. Article V(2)(a). In: WOLFF, Reinmar (ed). New York Convention on the Recognition and Enforcement of Foreign Arbitral Awards: Commentary. München: C. H. Beck, 2012, p. 390.

10 E.g. England. See Research on How the English Courts Address the Issue of Arbitrability in the Context of the New York Convention [online]. IBA Subcommittee on Recognition and Enforcement of Arbitral Awards, 2016, point 3. Available at: https://www.ibanet.org/ Accessed: 30.11.2017.

11 See Article 177(1) of the Swiss Private International Law Act, Section 1030(1) of the German Code of Civil Procedure, Section 582(1) of the Austrian Code of Civil Procedure. 
on the possibility of the parties to settle on the issue in dispute, ${ }^{12}$ or require the cumulative existence of both the conditions. ${ }^{13}$

\section{Arbitrability and Public Interest}

Public interest in international commercial arbitration must be distinguished from individual interests. The arbitrator's obligations are directed towards the parties to arbitration, and thus towards the protection of their individual interests. Public interests refer to those interests that go beyond those of the parties to the dispute. At the most general level public interest can be defined as certain collective values, ${ }^{14}$ or an interest benefitting a large group of individuals. ${ }^{15}$ In the context of arbitrability, public interest must be perceived as protection of higher values that are protected for the good of the society. ${ }^{16}$ Public interest has also traditionally been one of the criteria of classification of public and private law. International commercial arbitration is a method of resolution of private-law disputes. Arbitrability is particularly difficult regarding disputes that require the application of public law.

The definitions of arbitrability have traditionally been connected with public interest. An earlier approach, which has been superseded with modern views, states that a dispute is not arbitrable if it goes beyond individual interests of the parties to arbitration and concerns public interests. For this reason, a number of disputes was considered inarbitrable or their arbitrability was at least doubtful (e.g. disputes requiring the application of competition laws, disputes connected with criminal conduct, disputes related to insolvency proceedings, etc.). Many arguments in favour of inarbitrability of such disputes appeared over the time.

The first group of arguments could be referred to as procedural ones and includes the following views. In comparison with court proceedings, arbitration is characterized by less intensive fact-finding and evidence-taking, arbitral award contains only a limited reasoning or none at all, there is usually no second instance and control by national courts is restricted, arbitration is private and confidential. All the above arguments must be denied. Although arbitration differs from court proceedings, it is no compromise in terms of a fair trial. If that

12 See Section 1030(1) of the German Code of Civil Procedure, Section 582(1) of the Austrian Code of Civil Procedure, Article 2059 of the French Civil Code, Section 1 of the Swedish Arbitration Act.

13 Section 2 of the Czech Arbitration Act.

14 MATES, Pavel, BARTON, Michal. Public versus Private Interest - Can the Boudaries Be Legally Defined? In: BĚLOHLÁVEK, Alexander J., ROZEHNALOVÁ, Naděžda (eds). Czech Yearbook of International Law. Volume II. Juris Publishing, 2011, p. 172.

15 BĚLOHLÁVEK, Alexander J. Public Policy and Public Interest in International Law and EU Law. In: BĚLOHLÁVEK, Alexander A. J., ROZEHNALOVÁ, Naděžda (eds). Czech Yearbook of International Law. Volume III. Huntington: Juris Publishing, 2012, p. 126.

16 MATES, BARTOŇ, 2011, op. cit, p. 173. 
was the case, arbitration could not be used in "private disputes", either. Even purely private disputes require procedural guarantees. ${ }^{17}$

Another argument concerns the ability of arbitrators to correctly apply public law. The nature of the matter implies that arbitrators are authorized to consider only individual interests of the parties. Thus, they are not able to apply legal rules that aim at the protection of the society or a group of persons beyond the arbitration parties. Also this argument must be declined. First, it is rather difficult to accept the idea that all the judges automatically have this ability. Second, the application of legal rules is not automatic or dependent on subjective feelings of the person who applies them. There is no reason to a priori assume that an arbitrator is incapable of such task. ${ }^{18}$

The third argument consists in a concern whether arbitrators will apply rules protecting public interest. This does not mean that as a result of such concern, these disputes shall be excluded from arbitration. An arbitrator has an obligation to consider all the relevant circumstances and decide which rules to apply. ${ }^{19}$ Moreover, the practice shows that arbitrators in international commercial arbitration frequently apply public law rules, in particular overriding mandatory rules. $^{20}$ This argument thus cannot oppose arbitrability as such. However, it raises a number of questions concerning the arbitrators' duty to apply certain rules to the merits of the dispute and also the scope of control by national courts.

At present, there is no sign of equation between public interest and inarbitrability. If a certain dispute concerns public interest or requires the application of public law rules, it does not automatically mean that it is inarbitrable. ${ }^{21}$ Areas that were formerly perceived as belonging to the domain of national courts have gradually become victims of extension of the arbitrability scope. International commercial arbitration is now used also for economic claims which concern public interests. $^{22}$

Nevertheless, public interest is still reflected in the definition of arbitrability. Those disputes or proceedings that are closely connected with public interest and

17 BREKOULAKIS, Stavros L. On Arbitrability: Persisting Misconceptions and New Areas of Concern. In: MISTELIS, Loukas A., BREKOULAKIS, Stavros L. (eds). Arbitrability: International \& Comparative Perspective. Alphen aan den Rijn: Kluwer Law International, 2009, pp. 23-25.

18 Ibid., pp. 26-29.

19 Ibid., pp. 30-32.

20 YOUSSEF, Karim A. The Death of Inarbitrability. In: MISTELIS, Loukas A., BREKOULAKIS, Stavros L. (eds). Arbitrability: International \& Comparative Perspective. Alphen aan den Rijn: Kluwer Law International, 2009, p. 65.

21 MOURRE, Alexis. Arbitration and Criminal Law: Jurisdiction, Arbitrability and Duties of the Arbitral Tribunal. In: MISTELIS, Loukas A., BREKOULAKIS, Stavros L. (eds). Arbitrability: International \& Comparative Perspective. Alphen aan den Rijn: Kluwer Law International, 2009, p. 216.

22 YOUSSEF, 2009, op. cit., pp. 51-52. 
have to be dealt with by national courts have remained inarbitrable. This typically includes criminal proceedings, insolvency proceedings, succession matters etc. Due to the nature of these matters, arbitration is not a suitable method, either, because it cannot affect a large group of persons. ${ }^{23}$

Inarbitrability frequently concerns other areas than cross-border economic activities. This does not mean that we do not encounter inarbitrable disputes in this area. Although we may speak of public interest in the support of trade through an effective method of dispute resolution, ${ }^{24}$ which speaks in favour of support of the international commercial arbitration and extension of arbitrability, this public interest is always compared with other economic, social and, as the case may be, political interests ${ }^{25}$ which favour the maintenance of national courts' jurisdiction. These interests may differ in various countries, which is apparent in the various definitions of arbitrability.

\subsection{Violation of Competition Regulations}

The purpose of competition regulations is to protect and ensure free trade in a particular market. In the EU, the protection of competition is one of the fundamental aspects of the internal market. ${ }^{26}$ The EU, the United States and other developed countries prohibit agreements and practices leading to the prevention, restriction or distortion of competition or abuse of a dominant position. There is no doubt that competition regulations express an important economic public interest. Therefore, it had long been accepted that only national courts or other state authorities were entitled to assess circumstances, business practices and contractual provisions that might affect competition. This approach has been changing since the $1980 \mathrm{~s}^{27}$

We distinguish two ways of enforcement of competition rules - public law and private law. The former is enforced by competition authorities, in the EU by the Commission and by the Member States' competition authorities. The latter involves decision of disputes between private persons, which is in the jurisdiction of national courts and, as the case may be, arbitrators. Questions falling under the exclusive jurisdiction of competition authorities ${ }^{28}$ e.g. imposing public-law sanctions, granting block exemptions, authorization procedure etc., are not arbitrable. Arbitrators thus can play a role only in private-law enforcement.

23 BREKOULAKIS, 2009, op. cit., pp. 32-37.

24 QUINKE, 2012, op. cit., p. 389; MISTELIS, 2009, op. cit., p. 10.

25 LEW, MISTELIS, KRÖLL, 2003, op. cit., p. 199.

26 LEW, Julian D. M. Competition Laws: Limits to Arbitrators' Authority. In: MISTELIS, Loukas A., BREKOULAKIS, Stavros L. (eds). Arbitrability: International \& Comparative Perspective. Alphen aan den Rijn: Kluwer Law International, 2009, pp. 241, 242.

27 BORN, 2014, op. cit., pp. 975-976.

28 MOURRE, Alexis. Arbitrability of Antitrust Law from the European and US Perspective. In: BLANKE, Gordon, LANDOLT, Phillip (eds). EU and US Antitrust Arbitration: A Handbook for Practitioners. Alphen aan den Rijn: Kluwer Law International, 2011, p. 43. 
Only private-law claims may be brought to arbitration, arbitrators may decide on private-law consequences. The issue of violation of the prohibition to form cartels (in the EU Article 101 of the TFEU ${ }^{29}$ ) is most frequently resolved before arbitral tribunals. Such violation is either the basis of an action or it is objected by the defendant ${ }^{30}$ therefore, it can be both a sword and a shield. ${ }^{31}$ Arbitrators can also decide on claims for damages caused by anti-competitive conduct. ${ }^{32}$ It is currently widely accepted that private-law effects of competition rules' violation are arbitrable. ${ }^{33}$

An incentive starting this trend in the United States and in Europe was the well-known decision of the U. S. Supreme Court in Mitsubishi Motors Corp. v. Soler Chrysler-Plymouth, Inc. of $1985 .^{34}$ The impact of this decision upon the issue of arbitrability of disputes requiring the application of competition laws was enormous. It was also reflected in the area of EU competition regulation. The original enforcement of EU competition rules stressed the public-law approach and primarily fell under the Commission's jurisdiction. A substantial change was brought about by the Regulation 1/2003, ${ }^{35}$ which strengthened the role of private-law enforcement. The aim of the Regulation is the uniform interpretation and application of Articles 101 and 102 of the TFEU by national courts and competition authorities. The Regulation gives national courts and national competition bodies the authority to apply also Article 101(3). Until the adoption of the Regulation it was only the Commission that could decide on individual exceptions under Article 101(3) of the TFEU. ${ }^{36}$ Article 101(3) is therefore directly applicable (direct applicability of Article 101(1) and Article 102 had ensued previously from the case law of the Court of Justice). ${ }^{37}$

Although the Regulation 1/2003 is silent as regards arbitrations, the prevailing view is that arbitrators are entitled to exercise the same powers as national courts. ${ }^{38}$ They are entitled to contribute to private-law enforcement of EU com-

29 Treaty on the Functioning of the European Union.

30 DEMPEGIOTIS, Sotiris I. EC Competition Law and International Arbitration in the Light of EC Regulation 1/2003. Journal of International Arbitration, 2008, vol. 25, no. 3, p. 380.

31 RADICATI DI BROZOLO, Luca G. Arbitration and Competition Law: The Position of the Courts and of Arbitrators. Arbitration International, 2011, vol. 27, no. 1, p. 2.

32 DEMPEGIOTIS, 2008, op. cit., p. 380.

33 BORN, 2014, op. cit., p. 985; QUINKE, 2012, op. cit., p. 394; RADICATI DI BROZOLO, 2011, op. cit., p. 3.

34 Decision of U. S. Supreme Court of 2 July 1985, Mitsubishi Motors Corp. v. Soler ChryslerPlymouth, Inc. [online]. In: JUSTIA US Supreme Court. Available at: https://supreme.justia.com/cases/federal/us/473/614/case.html Accessed 01.12.2017.

35 Council Regulation (EC) No 1/2003 of 16 December 2002 on the implementation of the rules on competition laid down in Articles 81 and 82 of the Treaty.

36 LEW, 2009, op. cit., p. 254.

37 Preamble of the Regulation 1/2003, point 4.

38 LIEBSCHER, Christoph. Antitrust and Arbitration - A Status Report. In: KLAUSEGGER, Christian, KLEIN, Peter et al. (eds). Austrian Yearbook on International Arbitration, 2013, p. 115; VEEDER, V. V., STANLEY, Paul. Arbitrating Competition Law Issues: The Arbitra- 
petition rules. This was indirectly confirmed also by the Court of Justice in the case of Eco Swiss. ${ }^{39}$ International commercial arbitration most frequently deals with the issue of violation of Article 101 of the TFEU. In this context, arbitrators can deal with the question whether a contract or its provisions are prohibited under Article 101(1), whether a contract falls under a certain block exemption or if it is an individual exemption under Article 101(3). The application of Article 102 is not as frequent in the international commercial arbitration, however, is not excluded. ${ }^{40}$

From the viewpoint of EU law, it is possible to deal with and decide a dispute that requires the application of Article 101 or 102 TFEU in arbitration proceedings. However, we must realize that the EU law itself does not regulate the issue of arbitrability. The EU law merely admits private-law enforcement of competition rules and implies that it may be arbitrators who take part in such enforcement. Whether a certain dispute is arbitrable, depends on the opinion of the national law concerned.

For instance, the Swedish Arbitration Act expressly stipulates that arbitrators are allowed to decide on private-law effects of competition regulations between the parties. ${ }^{41}$ There are no problems with arbitrability in countries which use a broad criterion of a proprietary nature of a dispute (Germany, ${ }^{42}$ Switzerland, ${ }^{43}$ or Austria $\left.{ }^{44}\right)$. Arbitrability of such disputes has also been widely affirmed in England ${ }^{45}$ and France. ${ }^{46}$ Arbitrability of these disputes is also established under

tor's Perspective. In: BLANKE, Gordon, LANDOLT, Phillip (eds). EU and US Antitrust Arbitration: A Handbook for Practitioners. Alphen aan den Rijn: Kluwer Law International, 2011, pp. 97-98; LEW, 2009, op. cit., p. 255; DEMPEGIOTIS, 2008, op. cit., p. 380.

39 Judgment of the Court of Justice of 1 June 1999, Eco Swiss China Time Ltd v. Benetton International NV, Case C-126/97.

40 TRITTMANN, Rolf, KASOLOWSKY, Boris. EU Competition Law Arguments in International Arbitration: Practical Steps and Strategic Considerations. In: BLANKE, Gordon, LANDOLT, Phillip (eds). EU and US Antitrust Arbitration: A Handbook for Practitioners. Alphen aan den Rijn: Kluwer Law International, 2011, p. 181.

41 Section 1(3) of the Swedish Arbitration Act.

42 HANEFELD, Inka, TRITTMANN, Rolf. $\$ 1030$ - Arbitrability. In: BÖCKSTIEGEL, KarlHeinz, KRÖLL, Stefan M. et al. (eds). Arbitration in Germany: The Model Law in Practice. 2nd ed. Alphen aan den Rijn: Kluwer Law International, 2015, p. 101.

43 ORELLI, Mariella. Article 177 [Arbitrability]. In: ARROYO, Manuel (ed). Arbitration in Switzerland: The Practitioner's Guide. Alphen aan den Rijn: Kluwer Law International, 2013, p. 49.

44 KIMLA, Patrick, STEINHOFER, Stephan. Jurisdiction on Antitrust Disputes in Austria Relationship Between Arbitration and Litigation. In: ZEILER, Gerold, WELSER, Irene et al. (eds). Austrian Yearbook on International Arbitration, 2015, p. 27.

45 LEW, Julian D. M., MARSDEN, Oliver. Arbitrability. In: LEW, Julian D., M., Bor, Harris et al. (eds.) Arbitration in England, with Chapters on Scotland and Ireland. Alphen aan den Rijn: Kluwer Law International, 2013, p. 407.

46 BLACKABY, Nigel, PARTASIDES, Constantin, REDFERN, Alan, HUNTER, Martin. Redfern and Hunter on International Arbitration. 6th ed. New York: Oxford University Press, 2015, p. 114. 
the Czech Arbitration Act. They are proprietary disputes which would otherwise fall under the jurisdiction of courts. The condition of the existing possibility to settle the dispute is fulfilled also in case where the dispute concerns the validity or invalidity of a legal relationship. ${ }^{47}$ There are no problems with the last condition regarding the claims to fulfil an obligation or claims for damages.

\subsection{Disputes Affected by Illegal (Criminal) Practices}

In the area of international trade, arbitrability of disputes affected by corrupt practices is most often discussed. Corrupt practices are usually mentioned in connection with public funds, although the phenomenon is not restricted to that area. It may play a negative role also in private-law relations ${ }^{48}$ National regulations enable sanctioning corrupt practices both at the level of private and criminal law. Several important instruments have been adopted at the international level to fight corruption. ${ }^{49}$ There is no doubt that fight against corruption expresses a strong public interest.

There is no universal definition of corruption. It is usually perceived as offering or providing a bribe with the aim to influence another person's acts. The bribe need not be a sum of money, it can be anything of value - an expensive gift, paid holiday or a "study trip", procuring employment for children or a partner of the person. ${ }^{50}$ The Civil Law Convention on Corruption defines it as "requesting, offering, giving or accepting, directly or indirectly, a bribe or any other undue advantage or prospect thereof, which distorts the proper performance of any duty or behaviour required of the recipient of the bribe, the undue advantage or the prospect thereof". ${ }^{51}$ Czech legal regulation does not use the term corruption, but in the Criminal Code it works with the term bribery (Sections 331 to 334 of the Criminal Code).

Companies try to conceal bribes by means of transactions that appear to be legal, such as agency contracts, consultation contracts, partnerships, coopera-

47 ROZEHNALOVÁ, 2013, op. cit., p. 154; BĚLOHLÁVEK, Alexander J. Zákon o rozhodčím ř́zení a o výkonu rozhodčích nálezư. Komentář. 2nd ed. Praha: C. H. Beck, 2012, p. 125; decision of the Supreme Court, Czech Republic of 6 June 2007, no. 32 Odo 181/2006.

48 VALDHANS, Jiř́, ROZEHNALOVÁ, Naděžda, DRLIČKOVÁ, Klára, MÁLEK, Pavel. Consequences of Corrupt Practices in Business Transactions (Including International) in Terms of Czech Law. In: BONELL, Michael J., MEYER, Olaf (eds). The Impact of Corruption on International Commercial Contracts. Basel: Springer International Publishing, 2015, p. 99.

49 Convention on Combating Bribery of Foreign Public Officials in International Business Transactions (1997); Civil Law Convention on Corruption (1999), Criminal Law Convention on Corruption (1999); UN Convention against Corruption (2003).

50 ZIADÉ, Nassib G. Addressing Allegations and Findings of Corruption. In: BAIZEAU, Domitille, KREINDLER, Richard H. Addressing Issues of Corruption in Commercial and Investment Arbitration. Dossiers of the ICC Institute of World Business Law, 2015, vol. 13, p. 116. Available at: http://library.iccwbo.org/dr.htm Accessed 01.12.2017.

51 Article 2. 
tion contracts etc. These contracts may give rise to disputes, in which typically the agreed "commission" or "remuneration" is not paid. ${ }^{52}$ In case such contracts contain an arbitration clause, such disputes may be referred to arbitrators. In connection with corruption in the international commercial arbitration, two groups of disputes appear: disputes from contracts concluded for the purpose of bribery and disputes from contracts concluded as a result of bribery. In the former case, the parties enter into a contract whose subject is the provision of certain "services", which are only fictitious. In the latter it concerns a real business transaction, which is usually realized. However, its conclusion or fulfilment is affected by the provision of a bribe. ${ }^{53}$

Are arbitrators allowed to decide a dispute affected by corrupt practices? Literature dealing with this issue usually starts with the conclusions of a well-known Swedish arbitrator Lagergren from ICC award of 1963, No. 1110. The plaintiff was an important Argentinian businessman; the defendant was a British company operating on the Argentinian market. The defendant had been interested in supplying electrical equipment to the Buenos Aires region. It asked the plaintiff, who was an influential person in the politics and business, to support its offer. The parties entered into an agreement, under which the plaintiff was to obtain a certain percentage from contracts concluded by the defendant with Argentinian authorities as a commission. In the end, the defendant only concluded one contract, and refused to pay the commission to the plaintiff. Subsequently, the parties entered into an arbitration agreement and referred the dispute to a sole arbitrator in accordance with then valid ICC Rules. The venue of arbitration was France. The arbitrator, on his own motion, decided to review his jurisdiction and looked into the issue of arbitrability from the viewpoint of the French as well as Argentinian law. He concluded that he had no jurisdiction in the matter, because the case involved gross violation of good morals and international public policy and could not be tolerated by any court or arbitral tribunal in a civilized country. ${ }^{54}$

It is possible to derive from the above award that a dispute affected by corrupt practices of the parties is not arbitrable. The literature also mostly derives this conclusion. ${ }^{55}$ However, we can at least raise doubt whether this conclusion

52 ZIADÉ, 2015, op. cit., p. 117.

53 ARMESTO, Juan F. The Effects of a Positive Finding of Corruption. In: BAIZEAU, Domitille, KREINDLER, Richard H. Addressing Issues of Corruption in Commercial and Investment Arbitration. Dossiers of the ICC Institute of World Business Law, 2015, vol. 13, pp. 166, 168. Available at: http://library.iccwbo.org/dr.htm Accessed 01.12.2017.

54 ICC Award of 1963, no. 1110. In: VAN DEN BERG, Albert J. (ed). Yearbook Commercial Arbitration. Volume XXI. Kluwer Law International, 1996, pp. 47-53.

55 BLACKABY ET AL., 2015, op. cit., p. 120; BORN, 2014, op. cit., p. 990; LEW, MISTELIS, KRÖLL, 2003, op. cit., p. 215. 
really ensues from the award. Certain parts of the award suggest that the award does not in fact deal with arbitrability, but with the admissibility of the claim. ${ }^{56}$

This corresponds to the contemporary trend. Disputes affected by corrupt practices are arbitrable. ${ }^{57}$ Arbitrators are in such cases entitled to decide on the merits of the dispute. In other words, they have the jurisdiction to decide on the private-law sanction of such practices, which shall mostly result in the declaration of invalidity of the contract. ${ }^{58}$ Such approach was confirmed by arbitrators as well as by national courts. However, there are various definitions of arbitrability, and thus some countries may apply opposite approach..$^{59}$ Decisions on criminal sanction remain exclusively in the hands of national courts. Arbitrators may assess the criminal nature of the conduct only as a preliminary question necessary for the resolution of the dispute. ${ }^{60}$

More often than with arbitrability, this issue is connected with the validity of the arbitration agreement. The main contract affected with corrupt practices is usually invalid. However, due to the principle of separability, this shall not automatically affect the validity of the arbitration agreement unless it is invalid for the same reason. This is usually not the case, because the corrupt practices only affect the main contract. Thus, the arbitrator shall have the jurisdiction to decide in the matter itself, i.e. on the validity of the main contract. ${ }^{61}$

In connection with corrupt practices, the contemporary theory and the practice do not deal with the issue of arbitrability or validity of the arbitration agreement, but rather with issues concerning the resolution of the disputes before arbitrators, in particular under which law to assess corrupt practices, arbitrator's responsibility to ascertain corrupt actions on their own motion, burden of proof and notification duty of arbitrators. ${ }^{62}$

Disputes affected with other crimes may also be dealt with in arbitration. This includes but is not limited to economic crimes (such as money laundering,

56 MOURRE, 2009, op. cit., p. 211.

57 BLACKABY ET AL., 2015, op. cit., p. 119; BANAIFTEMI, Yas. The Impact of Corruption on „Gateway Issues“ of Arbitrability, Jurisdiction, Admissibility and Procedural Issues. In: BAIZEAU, Domitille, KREINDLER, Richard H. Addressing Issues of Corruption in Commercial and Investment Arbitration. Dossiers of the ICC Institute of World Business Law, 2015, vol. 13, p. 16. Available at: http://library.iccwbo.org/dr.htm Accessed 01.12.2017; NUEBER, Michael. Corruption in International Commercial Arbitration - Selected Issues. In: ZEILER, Gerold, WELSER, Irene (eds). Austrian Yearbook on International Arbitration, 2015, p. 4; ZIADÉ, 2015, op. cit., p. 119; BORN, 2014, op. cit., p. 990.

58 MOURRE, 2009, op. cit., p. 216.

59 BORN, 2014, op. cit., pp. 990-991.

60 BESSON, Sébastien. Corruption and Arbitration. In: BAIZEAU, Domitille, KREINDLER, Richard H. Addressing Issues of Corruption in Commercial and Investment Arbitration. Dossiers of the ICC Institute of World Business Law, 2015, vol. 13, p. 103. Available at: http:// library.iccwbo.org/dr.htm Accessed 01.12.2017.

61 NUEBER, 2015, op. cit., p. 5; QUINKE, 2012, op. cit., p. 397.

62 NUEBER, 2015, op. cit., p. 3. 
fiscal crimes, falsification of documents, violations of foreign trade regulations, etc.).

\subsection{Disputes Concerning Intellectual Property Rights}

The variety of intellectual property rights brings about the variety of disputes. These include disputes arising out of contracts involving intellectual property rights, disputes from violation of intellectual property rights, or disputes concerning ownership, validity or scope of the rights. In the international trade, disputes involving industrial property rights most often arise.

The protection of industrial property rights is in the public interest. ${ }^{63}$ Scientific and technological progress results in the protection of patents, the transparency of markets calls for the existence of trademarks. The existence of industrial property rights is contingent on their registration, which is fully in hands of the state. The issue of granting industrial property rights is an expression of the state sovereignty. The industrial property right is an absolute right with universal effect. A number of countries have enacted exclusive jurisdiction of special state authorities to decide on cancellation or validity of an industrial property right. ${ }^{64}$

The above premises are reflected in the issue of arbitrability of disputes concerning industrial property rights. Disputes about ownership, contracts and violation of the rights are in principle arbitrable. The only group of disputes begging the question for (in)arbitrability is disputes concerning validity or cancellation of registered rights. ${ }^{65}$

Several arguments can be put forth against the arbitrability of disputes concerning the validity of a registered right. Arbitrators cannot have the jurisdiction to decide on its invalidity or cancellation due to the fact that the right is granted by a state authority. Individuals cannot alter an act of the state through a private method of dispute resolution. It is the state that is authorized to decide on the cancellation or invalidity of the right. Private persons are not allowed to create rights with effects towards third parties, either. ${ }^{66}$

However, we must distinguish between the effectiveness of an industrial property right towards third parties and validity with effects inter partes. ${ }^{67}$ In most countries, arbitrators cannot decide on cancellation or validity of a right that has effects towards third parties. An arbitral award is only binding upon the parties to the arbitration proceedings. Nevertheless, national laws may extend the

63 See also KYSELOVSKÁ, Tereza. Intellectual Property Rights. In: ROZEHNALOVÁ, Naděžda, DRLIČKOVÁ, Klára et al. Czech Private International Law. Brno: Masarykova univerzita, 2015, p. 189.

64 COOK, Trevor, GARCIA, Alejandro I. International Intellectual Property Arbitration. Kluwer Law International, 2015, pp. 62-64.

65 Ibid., pp. 51, 52.

66 Ibid., pp. 62-63.

67 COOK, GARCIA, 2015, op. cit., p. 68; BORN, 2014, op. cit., p. 993. 
effects of an arbitral award so that it is effective on everyone. This is for instance the case of Switzerland, which is known for its liberal approach to arbitrability in this area. Swiss arbitrators can decide on the validity of patents, trademarks and designs, and the arbitral award serves as the basis for registration. ${ }^{68}$ This is not possible in the number of other countries, including the Czech Republic.

The issue of validity of an industrial property right most frequently appears as an objection in the proceedings whose subject matter is one of the above mentioned arbitrable disputes (e.g. a dispute ensuing from violation of the right). In such cases, arbitrators would only assess the validity as a preliminary question and their decision would have effects inter partes. If the arbitrator considered the right as invalid, he would "only" reject the claim from the violation of the right. The right would remain in effect towards third parties ${ }^{69}$ until the relevant state authority decides on its cancellation or invalidity. The arbitrability issue may differ here from country to country. To support arbitrability we can generally argue that the arbitrators' decision is only binding upon the parties to arbitration and has no effect on third parties. It is the state authority that must decide on such effect. The jurisdiction of arbitrators therefore does not conflict the jurisdiction of state authorities. ${ }^{70}$ Arbitrators are endowed with jurisdiction in such cases in Germany, Italy, France, Spain or Portugal. ${ }^{71}$ In my opinion, it is also possible under the Czech law that the validity of a right is adjudged by arbitrators as a preliminary question.

\subsection{Disputes Affected by Insolvency Proceedings}

The insolvency proceedings are of collective nature and their purpose is to maximize the value of the debtor's assets and to ensure equal treatment of its creditors. The aim of insolvency proceedings is not to resolve disputes between parties, but collective execution or reorganisation of the debtor. ${ }^{72}$ The proceedings should result in the settlement of proprietary relations with persons affected by the debtor's insolvency or impending insolvency. ${ }^{73}$ The way of resolution of the debtor's insolvency expresses strong public interest. Its purpose is not only to protect the interest of the debtor or of a particular creditor, but also the interest

68 MANTAKOU, Anna P. In: MISTELIS, Loukas A., BREKOULAKIS, Stavros L. (eds). Arbitrability: International \& Comparative Perspective. Alphen aan den Rijn: Kluwer Law International, 2009, p. 268.

69 COOK, GARCIA, 2015, op. cit., pp. 69-70.

70 BORN, 2014, op. cit., p. 993.

71 KYSELOVSKÁ, Tereza. Arbitrability of Intellectual Property Rights Disputes. In: BĚLOHLÁVEK, Alexander J., ROZEHNALOVÁ, Naděžda (eds). Czech (ఓ Central European) Yearbook of Arbitration. Volume VII. The Hague: Lex Lata, 2017, p. 91; COOK, GARCIA, 2015, op. cit., pp. 73, 74; HANEFELD, TRITTMANN, 2015, op. cit., p. 99.

72 KRÖLL, Stefan M. Arbitration and Insolvency Proceedings - Selected Problems. In: MISTELIS, Loukas A., LEW, Julian D. M. (eds). Pervasive Problems in International Arbitration. Alphen aan den Rijn: Kluwer Law International, 2006, pp. 358-359.

73 See Section 1 of the Act no. 182/2006 Coll., Insolvency Act. 
of all the creditors as well as of general public. This is the reason why insolvency proceedings as such are in the hands of courts, and their resolution in arbitration is not admissible. Arbitrators cannot decide on the insolvency of a debtor or on the method of its resolution. Literature speaks of "pure" insolvency issues in this context. $^{74}$

The issue of arbitrability of disputes related to insolvency proceedings is more problematic. Here, it is necessary to carefully assess whether the dispute is arbitrable in the country concerned. There are still many differences in this area. ${ }^{75}$

A separate issue, frequently addressed in international commercial arbitration, is the situation where the debtor is a party to the arbitration agreement and arbitration proceedings. This typically concerns the situation where insolvency proceedings are initiated after the commencement of arbitration. It is a complex problem that begs a number of partial questions, which do not have universal answers. ${ }^{76}$ The answers will differ country by country. The problematic relationship between the insolvency proceedings and arbitration proceedings results from their different goals. ${ }^{77}$ However, it is exceptional that such situation causes doubt about the arbitrability of the dispute. ${ }^{78}$ Initiation of insolvency proceedings usually does not affect the validity of existing arbitration agreements. Those are binding upon the insolvency trustee. A prevailing majority of legal systems connects the initiation of the insolvency proceedings with suspension of individual proceedings. ${ }^{79}$ What differs is the impact of such provisions on arbitration. ${ }^{80}$

\section{Conclusion}

The definition of arbitrability has remained in the domain of national law; there is no internationally unified definition, although a common trend towards the extension of its scope may be observed. At present, courts as well as arbitrators must assess arbitrability in accordance with a certain legal system. Arbitrability determines the jurisdiction of arbitrators and thus the borderline between

74 BLACKABY ET AL., 2015, op. cit., p. 117; BORN, 2014, op. cit., p. 995; LEW, MISTELIS, KRÖLL, 2003, op. cit., p. 206.

75 See e.g. Section 2 of the Czech Arbitration Act that excludes all incidental disputes from the scope of arbitrable disputes. Incidental disputes are defined in Section 159 of the Insolvency Act.

76 For detailed analysis see e.g. VORBURGER, Simon. International Arbitration and CrossBorder Insolvency: Comparative Perspectives. Alphen aan den Rijn: Kluwer Law International, 2014.

77 MAHDALOVÁ, Silvie. Application of European Insolvency Law in Arbitration Proceedings. In: DRLIČKOVÁ, Klára, KYSELOVSKÁ, Tereza (eds). COFOLA International 2016. Brno: Masarykova univerzita, 2016, p. 88.

78 BORN, 2014, op. cit., p. 996; KRÖLL, 2006, op. cit., p. 367.

79 The Court of Justice stated that it was the principle common to legal orders of Member States. Judgment of the Court of Justice of 17 March 2005, Commission of European Communities v. AMI Semiconductor Belgium BVBA and others. Case C-294/02.

80 For overview see VORBURGER, 2014, op. cit., pp. 183-191. 
the jurisdiction of courts and potential jurisdiction of arbitrators. Courts usually assess arbitrability according to their own law in all stages. Arbitrators should apply the law applicable to arbitration.

There is no doubt about arbitrability in disputes concerning only the individual interests of the parties. However, if the dispute shows elements of public interest, it does not automatically imply that it is not arbitrable. A sign of equation thus cannot be put between public interest and inarbitrability. Disputes arising from economic activities involving public interest can be resolved before the arbitral tribunals. This for instance includes private-law enforcement of competition rules (including EU ones), disputes affected by illegal (criminal) actions, disputes concerning intellectual property rights (in certain countries also with erga omnes effects) or disputes related to insolvency proceedings. The tendency towards the support of arbitrability is apparent in a number of countries (especially those sought as favourite arbitral seats). Arbitrability is currently a rule, inarbitrability an exception. This is also evidenced by the minimum number of refusals of recognition under Art. V(2)(a) of the New York Convention. ${ }^{81}$

\section{References}

ARMESTO, Juan F. The Effects of a Positive Finding of Corruption. In: BAIZEAU, Domitille, KREINDLER, Richard H. Addressing Issues of Corruption in Commercial and Investment Arbitration. Dossiers of the ICC Institute of World Business Law, 2015, vol. 13. Available at: http://library.iccwbo.org/dr.htm

ARROYO, Manuel (ed). Arbitration in Switzerland: The Practitioner's Guide. Alphen aan den Rijn: Kluwer Law International, 2013.

BANAIFTEMI, Yas. The Impact of Corruption on „Gateway Issues“ of Arbitrability, Jurisdiction, Admissibility and Procedural Issues. In: BAIZEAU, Domitille, KREINDLER, Richard H. Addressing Issues of Corruption in Commercial and Investment Arbitration. Dossiers of the ICC Institute of World Business Law, 2015, vol. 13. Available at: http:// library.iccwbo.org/dr.htm

BĚLOHLÁVEK, Alexander J. Public Policy and Public Interest in International Law and EU Law. In: BĚLOHLÁVEK, Alexander A. J., ROZEHNALOVÁ, Naděžda (eds). Czech Yearbook of International Law. Volume III. Huntington: Juris Publishing, 2012.

BĚLOHLÁVEK, Alexander J. Zákon o rozhodčím řizení a o výkonu rozhodčích nálezů. Komentár. 2nd ed. Praha: C. H. Beck, 2012.

BESSON, Sébastien. Corruption and Arbitration. In: BAIZEAU, Domitille, KREINDLER, Richard H. Addressing Issues of Corruption in Commercial and Investment Arbitration. Dossiers of the ICC Institute of World Business Law, 2015, vol. 13. Available at: http:// library.iccwbo.org/dr.htm

BLACKABY, Nigel, PARTASIDES, Constantin, REDFERN, Alan, HUNTER, Martin. Redfern and Hunter on International Arbitration. 6th ed. New York: Oxford University Press, 2015.

81 QUINKE, 2012, op. cit., p. 380. 
BLANKE, Gordon, LANDOLT, Phillip (eds). EU and US Antitrust Arbitration: A Handbook for Practitioners. Alphen aan den Rijn: Kluwer Law International, 2011.

BÖCKSTIEGEL, Karl-Heinz, KRÖLL, Stefan M. et al. (eds). Arbitration in Germany: The Model Law in Practice. 2nd ed. Alphen aan den Rijn: Kluwer Law International, 2015.

BORN, Gary B. International Commercial Arbitration. 2nd ed. Alphen aan den Rijn: Kluwer Law International, 2014.

COOK, Trevor, GARCIA, Alejandro I. International Intellectual Property Arbitration. Kluwer Law International, 2015.

Decision of the Supreme Court, Czech Republic of 6 June 2007, no. 32 Odo 181/2006.

Decision of U. S. Supreme Court of 2 July 1985, Mitsubishi Motors Corp. v. Soler ChryslerPlymouth, Inc. [online]. In: JUSTIA US Supreme Court. Available at: https://supreme. justia.com/cases/federal/us/473/614/case.html

DEMPEGIOTIS, Sotiris I. EC Competition Law and International Arbitration in the Light of EC Regulation 1/2003. Journal of International Arbitration, 2008, vol. 25, no. 3.

ICC Award of 1963, no. 1110. In: VAN DEN BERG, Albert J. (ed). Yearbook Commercial Arbitration. Volume XXI. Kluwer Law International, 1996.

Judgment of the Court of Justice of 1 June 1999, Eco Swiss China Time Ltd v. Benetton International NV, Case C-126/97.

Judgment of the Court of Justice of 17 March 2005, Commission of European Communities v. AMI Semiconductor Belgium BVBA and others. Case C-294/02.

KIMLA, Patrick, STEINHOFER, Stephan. Jurisdiction on Antitrust Disputes in Austria - Relationship Between Arbitration and Litigation. In: ZEILER, Gerold, WELSER, Irene et al. (eds). Austrian Yearbook on International Arbitration, 2015.

KYSELOVSKÁ, Tereza. Arbitrability of Intellectual Property Rights Disputes. In: BĚLOHLÁVEK, Alexander J., ROZEHNALOVÁ, Naděžda (eds). Czech (ఓ Central European) Yearbook of Arbitration. Volume VII. The Hague: Lex Lata, 2017.

LEW, Julian D. M., MISTELIS, Loukas A., KRÖLL, Stefan M. Comparative International Commercial Arbitration. The Hague: Kluwer Law International, 2003.

LEW, Julian D., M., BOR, Harris et al. (eds.) Arbitration in England, with Chapters on Scotland and Ireland. Alphen aan den Rijn: Kluwer Law International, 2013.

LIEBSCHER, Christoph. Antitrust and Arbitration - A Status Report. In: KLAUSEGGER, Christian, KLEIN, Peter et al. (eds). Austrian Yearbook on International Arbitration, 2013.

MAHDALOVÁ, Silvie. Application of European Insolvency Law in Arbitration Proceedings. In: DRLIČKOVÁ, Klára, KYSELOVSKÁ, Tereza (eds). COFOLA International 2016. Brno: Masarykova univerzita, 2016.

MATES, Pavel, BARTOŇ, Michal. Public versus Private Interest - Can the Boudaries Be Legally Defined? In: BĚLOHLÁVEK, Alexander J., ROZEHNALOVÁ, Naděžda (eds). Czech Yearbook of International Law. Volume II. Juris Publishing, 2011.

MISTELIS, Loukas A., BREKOULAKIS, Stavros L. (eds). Arbitrability: International \& Comparative Perspective. Alphen aan den Rijn: Kluwer Law International, 2009.

MISTELIS, Loukas A., LEW, Julian D. M. (eds). Pervasive Problems in International Arbitration. Alphen aan den Rijn: Kluwer Law International, 2006. 
NUEBER, Michael. Corruption in International Commercial Arbitration - Selected Issues. In: ZEILER, Gerold, WELSER, Irene (eds). Austrian Yearbook on International Arbitration, 2015.

RADICATI DI BROZOLO, Luca G. Arbitration and Competition Law: The Position of the Courts and of Arbitrators. Arbitration International, 2011, vol. 27, no. 1.

Report on the Concept of Arbitrability under the New York Convention [online]. IBA Subcommittee on Recognition and Enforcement of Arbitral Awards, 2016. Available at: http://www.ibanet.org/

Research on How the English Courts Address the Issue of Arbitrability in the Context of the New York Convention [online]. IBA Subcommittee on Recognition and Enforcement of Arbitral Awards, 2016. Available at: https://www.ibanet.org/

ROZEHNALOVÁ, Naděžda, DRLIČKOVÁ, Klára et al. Czech Private International Law. Brno: Masarykova univerzita, 2015.

ROZEHNALOVÁ, Naděžda. Rozhodči ř́zení v mezinárodním a vnitrostátním obchodním styku. 3rd ed. Praha: Wolters Kluwer ČR, 2013.

VALDHANS, Jiří, ROZEHNALOVÁ, Naděžda, DRLIČKOVÁ, Klára, MÁLEK, Pavel. Consequences of Corrupt Practices in Business Transactions (Including International) in Terms of Czech Law. In: BONELL, Michael J., MEYER, Olaf (eds). The Impact of Corruption on International Commercial Contracts. Basel: Springer International Publishing, 2015.

VAN DEN BERG, Albert J. The New York Arbitration Convention of 1958. The Hague: T. M. C. Asser Institute, 1981.

VORBURGER, Simon. International Arbitration and Cross-Border Insolvency: Comparative Perspectives. Alphen aan den Rijn: Kluwer Law International, 2014.

WOLFF, Reinmar (ed). New York Convention on the Recognition and Enforcement of Foreign Arbitral Awards: Commentary. München: C. H. Beck, 2012.

ZIADÉ, Nassib G. Addressing Allegations and Findings of Corruption. In: BAIZEAU, Domitille, KREINDLER, Richard H. Addressing Issues of Corruption in Commercial and Investment Arbitration. Dossiers of the ICC Institute of World Business Law, 2015, vol. 13. Available at: http://library.iccwbo.org/dr.htm 